\title{
ASSESSING AND MEASURING
}

\section{On quality in development-led archaeology}

Carolina Andersson, Agneta Lagerlöf \& Eva Skyllberg

\begin{abstract}
The concept of quality has become the subject of intensive discussion in almost all aspects of society in recent years and development-led archaeology is no exception. Results showing a lack of quality have been observed both in countries which choose to use systems based on competitive tendering and in those where developmentled archaeology is conducted solely by official institutions. In this article the authors discuss the essential elements for achieving good quality in developmentled archaeology as required by the Swedish Heritage Act. They also discuss how Swedish development-led archaeology can be enhanced and what is needed to achieve and maintain quality.
\end{abstract}

Key words: archaeology, development-led archaeology, quality, the development-led archaeological system, Heritage Conservation Act, KML

The Swedish Heritage Conservation Act (KML) states that development-led archaeology (Sw.uppdragsarkeologi) should be of good quality ('god kvalitet'). But what is meant here by good quality? In recent years the Swedish National Heritage Board has attempted to explain its definition of 'good quality' in development-led archaeology by means of regulations and guidelines. Regardless whether it is a special survey, field evaluation or excavation, assessing the good quality of an archaeological investigation is not easy. Quality is both complex and difficult to determine.

In this article we wish to discuss quality both as a general phenomenon and as a specific aspect of development-led archaeology. We will also present a brief overview of how other European countries organize 
their development-led archaeology and how this influences the qualitative results. With that as a background we will then focus on the development-led archaeological system in Sweden. What does the law say about quality? What are the fundamental elements of the system from a qualitative perspective? We will also discuss the expectations of society at large, that is, the aims of development-led archaeology and its benefit to society. Finally, we will open the door to the future. What can we do to enhance development-led archaeology? What efforts would promote an increase in quality and sustain it?

\section{THE CONCEPT OF 'QUALITY'}

Nowadays we use two different concepts of 'quality'. One (good qual$i t y$ ) is humanistic in its orientation while the other (correct quality) is technological (Sw. god kvalitet, rätt kvalitet, Nationalencyklopedin n.d.). Good quality is often a matter of assessment of, for example, the content of an archaeological report or the result of an archaeological investigation. Correct quality is mainly a matter of procedure and form; for example, that the tender submission document is correctly formulated in accordance with the specifications for development-led archaeology (KRFS 2007:2). Thus, good quality is assessed while correct quality is most often measurable.

The perception of quality, and the body responsible for its assessment, has changed over time. Prior to the Industrial Revolution the (master) craftsman guaranteed the quality of what was produced. Quality was a component of each separate product and the individual served as quality guarantor. In the industrial society quality assurance was instead integral to the production process. It was how it was done that was assessed, by means of, for example, the standards in ISO 9000. Quality meant reproducing the same quality in large numbers.

In our blue collar or information society the idea of quality lies mostly outside the product, in the realm of the user. What is important is who it is that receives a product or service. It is no longer a matter of assessment or measurement. The main focus is now directed to establishing which characteristics are important and who decides the agenda. Thus quality is also related to power, that is, to those deciding what is good. Within development-led archaeology the county administrative boards play a key role, as they are the representatives of society requesting the archaeological knowledge. This role requires not only clarity of communication but also the ability to balance the concerns of the various stakeholders. 


\section{EVERYONE IS TALKING ABOUT QUALITY}

Today, in the early 2 Ist century, quality is more topical than ever. We hear about quality management, quality control and quality assurance. The word 'quality' has become a mantra for progress and success and thereby risks becoming a superficial and hollow term. Its popularity stems perhaps from developments within the service sector, where there is overconfidence in the self-regulating power of the market and a focus on cost to the detriment of individual persons or groups. As previously state-run sectors become privatized and market oriented (for example, electricity, health care, care of the elderly, schools, child care), it becomes apparent that there is considerable risk that the worth of an activity drops if quality is not demanded, controlled and followed up. The significance of quality has thus become more obvious. Today quality is an important criterion both in commissioning and in evaluating a service, and thereby an important tool of competition.

With regard to development-led archaeology, market adaptation has resulted in the commissioner of an archaeological work becoming more precise about what is required, so that it sustains good quality. A further positive effect is that the various actors within development-led archaeology have gained a more professional attitude (precise orders, transparent evaluations, project planning, and quality assurance systems, etc).

The introduction of competition into development-led archaeology has, however, produced a series of negative consequences, especially in those countries in Europe where competition has advanced furthest and where regulations are few or almost nonexistent. One needs to recall the aim behind the whole system, and review the archaeological process, so as to safeguard scientific standards of quality.

Paradoxically, now that an emphasis on quality has entered the competition, the focus on high quality rather than on low price has more or less become a survival strategy for the competing applicants. Within development-led archaeology one must be able to show what good quality at a reasonable price is and what cost-effective development-led archaeology is all about.

\section{A VIEW OF EUROPE}

Intensive community expansion: the I992 Valletta Convention The proposals of the Convention on the protection of the archaeologi- 
cal heritage (European Treaty Series No I43), accepted in Valletta in Malta in I992, have been highly significant for development-led archaeology in Europe. The Valletta Convention came about as a result of the threat to the European cultural heritage from increasing largescale exploitation, decomposition due to environmental factors, and the occurrence of illegal and unscientific excavations.

The Convention stipulated a series of quality-raising measures such as extra legal protection, ensuring that investigations are carried out in a scientific manner, and that sufficient resources are available for financing an investigation. As a result of the Valletta Convention many European countries have legislated that the developer is responsible for the costs of the archaeological investigation caused by the developer's exploitations.

\section{Advances since 1992}

In the early I990s market forces were strong and, braced by the Valletta Convention and developer responsibility for costs, many countries introduced the element of competition into the development-led archaeological arena. Ireland and England were among the first to do so. Free competition was introduced and the developer alone negotiated the archaeological contract. It was considered that the system would in principle be self-regulatory and would not need any statements or binding legalities. No quality assurance systems or follow-up systems were introduced in either country.

Several other countries such as Holland, France and Sweden were influenced by this progress, especially by that in England, but chose to follow suit in varying degrees. In Holland a system similar to the English was introduced but with a detailed quality assurance system which all investigators are forced to follow. In France official institutions carry out all special surveys and field evaluations (a monopoly that is accepted by the EU), while excavations are submitted to competitive tendering. The state also controls the monitoring of the scientific quality. French development-led archaeological activity is strongly linked to academic research, and the state investigation bureau (INRAP) has its own research and development section.

Some countries chose not to introduce competition within development-led archaeology, and have argued that competition does not further good scientific quality. Examples are Hungary, Norway and Denmark. In Denmark and Norway development-led archaeology is exclusively run by the official institutions. It is likened to a research 
project and should therefore be carried out by a museum which undertakes research. Both countries maintain the vital importance of a link between development-led archaeology and research, and museums are therefore commissioned to conduct all development-led archaeological investigations. With the 'Scandinavian model' in mind, Hungary has so far chosen not to introduce competition.

Thus, there are a number of different development-led archaeological systems in Europe. The choice of a system has sometimes been the subject of intensive debate. In France the introduction of competition was preceded by a heated discussion in the media which was followed with great interest by several countries in Europe. France, however, still has a state monopoly alongside competition.

\section{Experience}

It is in countries with systems that are built on competition, to a greater or lesser extent, that the question of quality in development-led archaeology comes to the fore. The problems concerning quality can be summarised as follows:

- Price competition leads to low profitability, which in turn leads to the development-led archaeologists (or their firms) being unable to invest in competence, research or method development.

- Increased distance between development-led archaeology and the universities.

- The activity is viewed primarily as a service for developers, not as a stage in the research process.

- Inadequate financing of reports.

- Inadequate follow-up of the work process and its result.

A serious problem is that investigations tend to be carried out at such low costs that sufficient time is not allowed for report writing, which in turn results in a great amount of unwritten reports, or that reports are of such low quality that the dissemination of knowledge is hampered (see 'grey literature' in Pearce 2008). In the end, the state often has to go in with funds so that the investigation can be completed, or alternatively so that the information gathered can be disseminated (APPAG 2003; Doyle 2008; Pearce 2008; Lüth 2008). In order to guarantee that society will have access to knowledge of the past, several countries such as England and Ireland have thought it necessary for 
the state to take more responsibility for quality aspects and monitor these by means of regulations, guidelines, quality assurance systems, national or regional research programmes, follow-up, and evaluation (e.g. APPAG 2003; University College Dublin and Heritage Council 2006; Expert Advisory Committee, Department of the Environment, Heritage and Local Government Dublin 2008).

Even countries that have not introduced competition have had problems with sustaining scientific quality and with focusing on meaningful generation and dissemination of knowledge. In a recently completed overhaul concerning the generating of knowledge within Danish development-led archaeology, it was established that to divide these investigations among many small museums can be a problem in terms of establishing a dynamic archaeological research atmosphere. In addition there is a need, on a national level, for establishing guidelines and conditions for deeper analysis. Examples of problems in quality encountered in the Danish system include:

- Scientific analysis and publication beyond the basic reports are not included in the commission/tender.

- Considerable distance between development-led archaeology and the universities.

The problem of increased distance to universities and the importance of stimulating cooperation between field archaeologists and the universities has been stressed by among others Adrian Oliver of English Heritage, who partook as an external expert in the overhaul of the Danish archaeological system in 2009 (Oliver 2009). The problem also exists in England and can be linked to the changing role of the universities from both teaching and research institutes to primarily teaching ones. This has also been the case in Sweden where funding to universities is determined mainly by the number of registered students.

\section{The present: the need for quality and quality assurance}

Recently, critical voices have been raised from several countries concerning a present lack of quality or the risk of such, stressing the imperative need for some form of state control over development-led archaeological activity (Willems \& Brandt 2004; Willems \& Van den Dries 2007; Hinton \& Jennings 2007; Demoule 2007).

At the European Association of Archaeologists Conference in 2005 
quality assurance was made one of the themes on account of the ever hardening competitive climate in development-led archaeology (EAA 2005), and in 2008 an extensive session was organized for the exchange of experience and to discuss the effects of the Valletta Convention (EAA 2008). Poland, for example, expressed concern that the outcome there had in fact been quite the opposite to the intentions of the Convention. Representatives of several European countries thought that quality must now be the focus in order to fulfil the aims of development-led archaeology.

In a competitive system the winners of a tender are those who claim to produce the best goods at the best price, which is not necessarily the same as the lowest price. In order for this system to function the buyer must have a primary interest in the goods and be able to assess his quality of the goods. Within development-led archaeology the buyer, in those countries that have free competition, is the developer. In such a market the most important feature that the supplier, i.e. the investigating archaeologists, can compete with, is price. Without well-functioning state regulations, quality assurance systems and qualified monitoring and follow-up, there is a great risk that standards will drop to an unacceptable level. One of the clearest examples of this is the present situation in Ireland (University College Dublin and Heritage Council 2006; Department of the Environment, Heritage and Local Government Dublin 2008). In England the archaeological community stresses the importance of quality assurance of 'process, product and person' (Hinton \& Jennings 2007).

The countries that are uncertain about whether to adopt a competitive system, such as Hungary, wish to begin by building up a good quality assurance system. Uncertainty primarily concerns the fear of jeopardizing the scientific quality (Gábor 2008). There is great consensus among European countries that a development-led archaeological investigation is a scientific process which raises special demands for quality assurance. The major archaeological investigators in England and France (Oxford Archaeology and INRAP) have the support of academic committees of researchers (Oxford) or a research department (INRAP). In Denmark and Norway archaeological councils or researching university museums have been created, which support the central state agency in assessing larger projects, project planning and reports. In Holland there is a state inspector whose job is to follow up and evaluate the quality of development-led archaeology (Van den Dries \& Willems 2007). 
In all development-led archaeological systems, both competitive and non-competitive, there must be a built-in function to ensure quality in terms of both form and content.

\section{A SWEDISH PERSPECTIVE}

\section{Quality and the law}

It is vitally important that binding legal regulations emphasize the importance of standards of good quality in the development-led archaeological process.

The Swedish Heritage Conservation Act (KML) states:'The county administrative board shall ensure that the investigation meets good scientific standards and is executed at a cost that is not higher than is advocated by the circumstances' (KML I988: 950, chapter 2, sections II and I3).

Standards of good quality in scientific contexts are usually defined as the production of new or meaningful knowledge, that is, originality, potential knowledge gain, and scientific renewal. The law also emphasizes the importance of the 'costs not being higher than were advocated', which is a central concept in development-led archaeology and must be balanced against society's resources. In the relevant regulations and general recommendations for implementation of the Act (KRFS 2007:2) this is equated with cost effectiveness.

With regard to development-led archaeology, these regulations define the concept 'quality' as 'all the factors upon which the county administrative board places significance when judging a project design: an investigator's competence and organization, scientific quality, longterm dissemination of knowledge, etc. The term also concerns the level of goal attainment'. The concept 'good scientific quality' is defined as the 'use of scientific methods to acquire meaningful knowledge of relevance to authorities, research, and the general public. This requires that the result be made available and useful to the various interested parties' (KRFS 2007:2).

\section{New focus}

When the revised regulations came into force in 2008 , development-led archaeological work was set in relation to the overall goals of cultural heritage management. In the first paragraph of the revised regulations it is stated that the county administrative boards shall ensure that the goals prescribed by the Swedish parliament (Riksdagen) for the cul- 
tural environment are used as guidelines for archaeological investigative activity. The goal that is most relevant here is 'each and everyone's understanding of, participation in, and responsibility for the own cultural environment'.

This link to the overall goals of cultural heritage management has given the Heritage Board the opportunity to clarify the aim of development-led archaeology and open up a new focus. We wish to emphasize that development-led archaeology should include both scientific documentation and dissemination, along with communication, with a view to creating an understanding of its significance for archaeological knowledge and archaeological investigations. Scientific documentation is no longer the aim but the means. The aim should be to transform and present the results of the investigation for the different target groups in an interesting and relevant manner. By widening the concept of reporting beyond the mere written account, the county administrative boards are given the opportunity to initiate and commission other forms of communication and dissemination of the results.

The significance of archaeological sites for society is clarified by, for example, the increase in information which is generated by their excavation, and the experiences and reflections which the work generates among people. Today, development-led archaeology is one of the major sources of new archaeological knowledge. But the mere collection of data during an excavation, followed by interpretation and presentation in a report, does not mean that society automatically has access to the data. The generation of knowledge is an active process. Data can only become knowledge when interpreted, communicated and used. The most important duty of archaeologists must be to interpret and present their results in such a way that they are relevant, usable, and accessible to all. For this to be accomplished, it is essential that the whole development-led archaeological process is permeated with an awareness of the highest quality of standards and the way to achieve it.

\section{CRITICAL ELEMENTS IN DEVELOPMENT-LED ARCHAEOLOGY}

The concept of best practice is referred to in the guidelines for applying the statements of the Swedish National Heritage Board (KRFS 2007:2). But reality is complex and can involve conflicting interests and unprecedented difficulties. In the following section we will discuss quality in development-led archaeology on the basis of some of the most essential elements in the process. 


\section{Commissions/Tenders}

The law states that the county administrative boards are responsible for ensuring good quality in archaeological investigations. The boards are the commissioners of the investigations and construct the submission document, that is, specification, which is the basis for the investigation project design, in order to make the process legally correct and transparent for all involved, developers as well as archaeologists. Thus responsibility for both a legally correct process and the quality content of an investigation rests with the county administrative boards. The board's staff should be experts at balancing different interests in society, and in particular be able to weigh the need for the requisition of land against cultural historical values. When commissioning development-led archaeology the boards must also ensure that they have the competence to assess both the research value of the investigation proposal and the credibility of the economic calculations supplied. A further complication, built into the development-led archaeological system, involves the need for a certain amount of competitive tendering for larger investigations. The county administrative board should also, in its role as monitor, assess goal achievement and evaluate the results of the archaeological investigation with regard to scientific quality and benefit to society. In a competitive system the board's supervision and evaluation becomes especially important as a guarantee for maintaining quality. The county boards must also assess the investigator's system for knowledge generation and dissemination; in other words, the methods used by the investigator to spread knowledge of the results throughout the scientific community, for example through publications, articles, conferences and debates (KRFS 2007:2, section 7).

Reality does not always follow good intentions. Much of the administrative work at the county boards is carried out against the clock. It is also impossible for an individual administrator to be competent in all areas. This can have various consequences. The board may choose to offer only broad guidelines for the direction of the investigation and its level of ambition or thoroughness, and then leave it to the investigator to formulate the plan of action. It has sometimes happened that the board has specified the aim and direction of the investigation so narrowly as to restrict the investigator's creativity and chances for groundbreaking research. The boards' administrators must have substantial competence to be able to guide an investigator onto the right track and stimulate qualitative research questions. Establishing networks is im- 
portant in this regard, as is collaboration with county administrative boards which provide wider and more creative environments of quality.

\section{Level of ambition}

Sufficient resources are necessary to produce an adequate basis for a decision, or to conduct an investigation of high quality in terms of both fieldwork and scientific interpretation, and to communicate the results. The formulation of a level of ambition for an investigation is a critical factor. This can be very marked in the case of a field evaluation, which is the basis for a decision regarding any further excavation. The field evaluation can be said to be a key factor in the success of the process as a whole.

A well-balanced level of ambition is also vital for the cost-effectiveness of an investigation. When an investigation costs large sums of money, products and knowledge of great value for society must be produced. The county administrative boards have the difficult task of promoting archaeology before other interests in society, and in their commissions they must be forceful enough to demand archaeology of good quality.

\section{Sufficient time}

A factor that is partly connected with the above argument is scarceness of time. This does not concern development-led archaeology alone, but is characteristic of much of the planning in society today. Building projects are steered to a great extent by budgets and political decisions. Furthermore, society's primary focus is never on archaeology but on the activity which gives rise to the investigation.

For development-led archaeology the time factor is a top priority. The process in which permits are granted by the county administrative boards determines the cultural landscapes that we hand down to future generations, and is thus a process that should not be hurried. In archaeological investigations time is not only limited by the amount of resources, but also by a lack of real time, partly on the practical level in order to administrate complicated investigations, and partly so that analyses are ready before the final interpretations are formulated. Large-scale investigations contain major research factors that demand time for consideration, which cannot be forced without adversely affecting their quality.

Then there is the aspect of calendar time or the seasons. Gener- 
ally speaking the building industry has developed into a year-round enterprise. All consultants, and this includes archaeologists, are now expected to be active during the winter months. Archaeological fieldwork, however, is not a matter of digging ditches or laying down pipelines but discerning and interpreting various colour changes in the soil and collecting very small artefacts. The quality of fieldwork is greatly dependent on weather conditions, and work under poor lighting and in the cold should be totally avoided. However, this is not always possible today. Archaeologists are forced to be active during most of the year. Sometimes important investigations have to be conducted in severe winter conditions.

\section{The archaeological craft}

Much of archaeological knowledge is based on experience. Besides being able to relate to previous research and theories, an archaeologist must also recognise artefacts and sites which may be hidden, fragmentary or in poor condition. For a field archaeologist there is the additional need to be able to choose methods that are suitable for each specific type of site and situation. In other words, it is a matter of extracting information from soil of different nuances and consistencies. Archaeologists dealing with development-led archaeology must be able to formulate relevant questions in a very short time, and address material which they did not choose in the first place. The material, i.e. the archaeological site, is in addition only partly known in advance. The quality of the archaeologists' work is to a very high degree determined by the ability to be flexible and adaptable throughout the entire investigation process.

Each investigation offers new primary material which can be used for rewriting history. This is not always apparent to the uninitiated from a report. Documentation and finds may be utilised in an unimaginable amount of studies and analyses, of which only a fraction are carried out during the investigation. In other words the material from an investigation still contains a large part of its direct research potential when it is placed in libraries, archives and stores. The documentation is analysed, interpreted and packed away in reports and articles, to be of later service to research and society.

The quality of the knowledge that comes from an investigation is always dependent on the quality of the archaeological craft. It can never be said too often that archaeological excavations cannot be repeated! The documentation and finds are all that survive, and ideally it should 
be possible to use them for a host of different topics and studies. It comes down to strict scientific accuracy, sufficient time and quality assurance.

The documentation of an investigation is determined by the method of reporting and of finds management. The quality of the documentation (i.e. database) shows how well the investigator carried out the investigation; in a report it is easier to hide any shortcomings. To ensure that the investigation can lead to major opportunities for study and analysis, both within the confines of the investigation and afterwards, a carefully prepared strategy, adherence to accuracy, and sufficient time are required. In a stressful situation governed by financial resources, there is a risk that documentation will become schematised or that standards of quality assurance will be lowered.

\section{Reaching out}

In the present system of development-led archaeology an investigation should in the first hand provide a report on which to base future research. The universities today are mainly centred on teaching and can only carry out research on a small part of the contract-archaeological material. This in turn means that the potential of this material is seldom fully utilised. Application of current legislation has meant that the contextualization, communication and dissemination of the results beyond what is achieved by the written report are not considered to lie within the mandate of the contract. The county museums have been suggested as further disseminators but this seldom happens.

The concept of 'reporting' (rapportering), as defined in the revised statements (KRFS 2007:2), includes all documentation that is produced during an investigation where material is described, interpreted and presented. Reporting should be related to the target groups. This should be viewed in the context of the new focus of development-led archaeology as discussed above, where the developer's burden of cost, where relevant and suitable, not only covers basic documentation (site recording, etc.) but also a critical scientific publication and a popularized account, or some other form of reporting. We cannot measure the quality of development-led archaeology until the results are transposed into knowledge and are discussed among those in both the archaeological world and society in general.

Results are communicated to the research community in written form through reports and articles and verbally in seminars and lectures. Efforts are made to communicate with the public as long as the 
investigation is in progress. When the public visits the excavation site the archaeological investigation provides not only information about the past but also insights into the growth of the cultural landscape, and gives rise to interesting reflections about the necessities of life for countless generations, etc.

The last 30 years of development-led archaeology have produced a considerable amount of primary material, opening up new inroads into prehistory and the Middle Ages. Completely new images of many periods and places have been obtained. However, this new information is not as available to society as it should be, given the amount of work put into its retrieval. The idea behind development-led archaeology must surely be that as many people as possible are able to comprehend the knowledge attained and that they should find this knowledge relevant and interesting. The fact that development-led archaeology does not always reach its target groups has several likely causes.

The reporting that is done at present is not sufficient for reaching the great number of people in society who are interested in history and archaeology. This requires that the results be presented firstly in a way that makes them accessible to different groups, and secondly through the right channels to reach them. This often demands considerable reworking of the findings and a high degree of interpretation.

The results from a single investigation are rarely significant without first being analysed together with the results of other investigations. A further level is required if the results are to be suitable for scientific journalism. At present the large infrastructural undertakings that include archaeological investigations provide the greatest surplus value to society. From these large ventures we are often provided with concluding scientific interpretations, popularized accounts, as well as lectures and guided tours for the public. However, the budget of the present system covers only fieldwork and the investigation report. Possibilities for syntheses and larger presentations are highly limited. Such are considered to lie outside the scope of development-led archaeology, which thereby becomes synonymous with basic research and purely regional character. The project nature of development-led archaeology also means that there is a definite cut-off as soon as the budget is used up and the final report submitted. The development-led archaeologist must immediately seek out the next contract, dropping all contact with the previous investigation, physically and mentally. 


\section{Public planning}

Archaeological investigation should provide a qualitative input into public planning, with relevance to a sustainable use of the landscape and the cultural environment. Collaboration between the developer and the county administrative board is vital at an early stage. If all important matters are laid on the table success is guaranteed in the ongoing process. The outcome of development-led archaeology is to a great extent determined by the degree of cooperation between the different parties involved.

A considerable amount of public planning material is gathered when making an archaeological impact assessment and evaluation. While the primary aim is to gain information about archaeological sites within the area under development, a range of analyses and reports are drawn up with wider relevance to general public planning of the environment and landscape. This information is of interest not only to county administrative boards but also to municipal authorities. But we have already noted that the results of archaeological investigations are not readily integrated in detailed development plans in the same way as other impact assessments are. In the actual exploitation project this information has a natural and immediate role to play, but a large part of the findings have even greater value than this. For example, a major untapped potential lies in the integration of the conclusions in the municipal comprehensive plans. But there is no tradition of collaboration between municipal authorities and archaeologists on such far-reaching issues. Reviews of investigations that have been carried out would be considerably eased by an investigation register.

\section{CHALLENGES OF THE FUTURE}

The discussion above shows that there is a great need for continued efforts to increase the adequacy of the development-led archaeological system and to improve its quality. What aspects do we wish to retain and what should we develop? During a conference on quality in Swedish development-led archaeology held in 2009 this problem was brought up and many new ideas were aired (Riksantikvarieämbetet 20I0).

The county administrative boards are a key factor in the system. Many evaluations and reports have pointed out the problem of shortcomings in their resources (Riksantikvarieämbetet 2004; SOU 2005:80; Wetterberg 2008). The Heritage Board has produced guidelines and 
held seminars and conferences with the aim of supporting the county administrative boards, but this is not sufficient. The networks that have been created between the different boards aid the exchange of competence and the creation of high-quality milieu (cf. Länsstyrelsen Södermanlands län 2009). But this falls short in the case of large-scale developments, with evaluation of project designs almost on a level with applications for full research projects. Sweden has no group of expert advisors that the country administrative boards can turn to. There have been previous attempts (I995-200I) with research coordinators and so-called controllers. Perhaps it is time to take up the question of special competence once again in support of the county administrative boards, or to formalize cooperation between the different boards. This is an area of great potential for furthering cooperation between authorities and universities.

According to recent statistics, about $\mathrm{I} 200$ archaeological investigations are carried out each year in Sweden, of which approximately I 50 are excavations (Riksantikvarieämbetet 2008). The findings from development-led archaeology are very fragmented because they are often published only in reports that relate to each separate investigation. Syntheses and summaries would in our opinion make these results far more accessible to people outside the archaeological community. Development-led archaeology is in great need of summary conclusions and syntheses on a national level, which can be used as a foundation for scientific journalism and for history writing of interest to the greater public. Both geographical and thematic syntheses are needed. This, however, cannot happen within the present system where the budget is restricted to the investigation of a single site. It is also unreasonable that such a cost be placed on the developer. A formalised opportunity to write syntheses would probably produce a marked rise in quality, both scientifically and communicatively.

To further improve the flow of knowledge, the dialogue between the various actors needs to be strengthened within both development-led archaeology and society at large. Today there is no forum or formulated goals for the long-term generation of knowledge within development-led archaeology, either on a regional or national basis. One way to eliminate the current shortcomings in the dialogue would be to provide regional strategies for archaeology. With the county administrative boards in a central position, the idea would be that the different actors and interest groups together formulate what they wish to achieve with 
development-led archaeology in their county or region. It is envisaged that relevant questions would be discussed, and gaps in knowledge that became apparent would advance coordinated opinion about relevant issues. Another possibility is to have museums become more involved and to call them in at an early stage in the investigation process.

There is no national quality assurance for the outcome of development-led archaeology. Today the county administrative boards hold full responsibility for monitoring the scientific quality of an investigation. These boards, however, have a regional perspective and find it difficult to carry out quality control and assess the scientific value of the results. Some European countries, for example France and Denmark, have a multifaceted system for quality assessment as well as a stronger organization such as a national quality evaluation council. Is this something that Sweden could try?

Carolina Andersson, Riksantikvarieämbetet / The Swedish National Heritage Board, Samhällsavdelningen, Box 5405, I I 484 Stockholm, Sweden

Agneta Lagerlöf, Riksantikvarieämbetet / The Swedish National Heritage Board, Samhällsavdelningen, Box 5405, I I 484 Stockholm, Sweden

Eva Skyllberg, Riksantikvarieämbetet / The Swedish National Heritage Board, Samhällsavdelningen, Box 5405, I I 484 Stockholm, Sweden

\section{References}

APPAG 2003. The Current State of Archaeology in the United Kingdom. First Report of the All-Party Parliamentary Archaeology Group. London. (www.sal.org.uk)

Demoule, J.P. 2007. Scientific quality control and the general organization of French archaeology. In: Willems, W. \& Van den Dries, M. (Eds). Pp. I35-I 47. Quality Management in Archaeology. Oxford: Oxbow.

Doyle, I. 2008. "Archaeological Research in Ireland: Recent Developments". Conference paper in EAA session Models of Delivering Research in Developmentled Archaeology. EAA I4th Annual Meeting. Malta I6-2I September 2008. Abstracts book. Pp. I7I. Valletta: University of Malta.

EAA 2005. European Association of Archaeologists, Conference session Quality assurance in archaeology.

EAA 2008. European Association of Archaeologists, Conference session From the Cradle to the Horizon: the Valletta Convention and the Future of European Archaeology.

Expert Advisory Committee, Department of the Environment, Heritage and Local Government Dublin 2008. Review of Archaeological Policy and Practice. Dublin.

European Treaty Series No.I43. European Convention on the Protection of the Archaeological Heritage (Revised) Valletta, I6.I.I992. Council of Europe. 
Gábor, V. 2008. “Archaeology and Development: Who Will Bite the Dust? Looking for a Working Model of Archaeology in Hungary". Conference paper in EAA session Models of Delivering Research in Development-led Archaeology. EAA I4th Annual Meeting. Malta I6-2 I September 2008. Abstracts book. P. I72. Valletta: University of Malta.

Hinton, P. \& Jennings, D. 2007. Quality management of archaeology in Great Britain: present practice and future challenges. In: Willems, W. \& Van den Dries, M. (Eds). Pp. Ioo-I I 2. Quality Management in Archaeology. Oxford: Oxbow.

KML. Lag (I988:950) om kulturminnen m.m. (SFS I988:950). The Heritage Conservation Act (1988:950).

KRFS 2007:2. Riksantikvarieämbetets föreskrifter och allmänna råd avseende verkställigheten av 2 kap. IO-I3 SS lagen (I988:950) om kulturminnen m.m. (www. raa.se)

Lüth, F. 2008. Discussion report. Council of Europe, Committee on Culture, Science and Education, Conference on Rescue Archaeology. Paris.

Länsstyrelsen Södermanlands län 2009. Samverkan ger styrka! Redovisning av uppdrag 39 i 2009 àrs regleringsbrev I juni 2009. Rapport nr 2009: I. Stockholm: Länsstyrelsen Södermanlands län.

Nationalencyklopedin n.d. (www.ne.se).

Oliver, A. 2009. International evaluation of knowledge development in connection with archaeological investigation activities under the new Danish Museum Act 2002. Unpublished Report.

Pearce, M. 2008. “Grey Literature: The Philosopher's Stone?”. Conference paper in EAA session Models of Delivering Research in Development-led Archaeology. EAA I 4th Annual Meeting. Malta I6-2 I September 2008. Abstracts book. Pp. I70-I7I. Valletta: University of Malta.

Riksantikvarieämbetet 2004. Uppdragsarkeologi 2003 och 2004. Uppgifter om den uppdragsarkeologiska verksambeten och länsstyrelsens handläggning av ärenden enligt 2 kap. I I-I 4 SS KML under åren 2003 och 2004. Stockholm: Riksantikvarieämbetet.

Riksantikvarieämbetet 2008. Tillämpning av 2-4 kap. Lagen (I988:950) om kulturminnen m.m. Statistik gällande 2007. Rapport från Riksantikvarieämbetet 2008:6. Stockholm: Riksantikvarieämbetet.

Riksantikvarieämbetet 20I0. Dokumentation frän Riksantikvarieämbetets konferens om kvalitet i uppdragsarkeologin 23-24 november 2009. Stockholm: Riksantikvarieämbetet.

SOU 2005:80. Uppdragsarkeologi itiden. Betänkande av Uppdragsarkeologiutredningen.

University College Dublin and Heritage Council 2006. Archaeology 2020. Repositioning Irish Archaeology in the Knowledge Society. A realistic achievable perspective. Dublin.

Van den Dries, M \& Willems, W. 2007. Quality Assurance in Archaeology, the Dutch Perspective. In: Willems, W. \& Van den Dries, M. (Eds). Quality Management in Archaeology. Pp. 50-65. Oxford: Oxbow.

Wetterberg, O. 2008. Utredning angående uppdragsarkeologin. Unpublished Report. Göteborg.

Willems, W.J.H. \& Brandt, R.W. 2004. Dutch Archaeology Quality Standard. Haag: Rijksinspectie voor de Archeologie.

Willems, W. \& van den Dries, M. 2007. The origins and development of quality assurance in archaeology. In: Willems, W. \& Van den Dries, M. (Eds). Quality Management in Archaeology. Pp. I-I 2. Oxford: Oxbow. 